\title{
Comparing the Early Research Performance of PhD Graduates in Labor Economics in Europe and the USA ${ }^{1}$
}

\author{
Ana Rute Cardoso* \\ IAE Barcelona (CSIC) and IZA \\ Paulo Guimarães \\ Darla Moore School of Business, University of South Carolina \\ Klaus F. Zimmermann \\ IZA, Bonn University and DIW Berlin
}

December 15, 2008

\begin{abstract}
This paper analyzes the early research performance of $\mathrm{PhD}$ graduates in labor economics, addressing the following questions: Are there major productivity differences between graduates from American and European institutions? If so, how relevant is the quality of the training received (i.e. ranking of institution and supervisor) and the research environment in the subsequent job placement institution? The population under study consists of labor economics $\mathrm{PhD}$ graduates who received their degree in the years 2000 to 2005 in Europe or the USA. Research productivity is evaluated alternatively as the number of publications or the quality-adjusted number of publications of an individual. When restricting the analysis to the number of publications, results suggest a higher productivity by graduates from European universities than from USA universities, but this difference vanishes when accounting for the quality of the publication. The results also indicate that graduates placed at American institutions, in particular top ones, are likely to publish more quality-adjusted articles than their European counterparts. This may be because, when hired, they already have several good acceptances or because of more focused research efforts and clearer career incentives.
\end{abstract}

Keywords: graduate programs; research productivity.

JEL codes: A23, J44, A11, A14, A10.

\footnotetext{
1 We thank Daniela Goed for valuable support throughout the data collection stages of this project. We are grateful to Dan Hamermesh and the participants in the "IZA Workshop on Research in Economics: Rewards, Evaluation and Funding" and the "IZA Anniversary Conference: Frontiers in Labor Economics" for very helpful comments, to the PhD graduates who replied to our inquiry to complete missing demographic information, and to the Barcelona GSE Research Network and the Government of Catalonia for financial support.

* Corresponding author: Ana Rute Cardoso, IAE Barcelona (CSIC), Institute for Economic Analysis, Spanish National Research Council, Campus UAB, 08193 Bellaterra, Barcelona, Spain. E-mail: anarute.cardoso@iae.csic.es
} 


\section{Introduction}

Predicting the early academic success of PhD graduates by looking at their research productivity or the quality of their job placement has been an issue of interest in economics. Studies on this subject are most often based on the idea that the research performance of the young $\mathrm{PhD}$ graduate is determined by the quality of the academic training received: namely, the quality of the institution awarding the $\mathrm{PhD}$ or the research productivity of the supervisor. Examples of such studies include Athey, Katz, Krueger, Levitt and Poterba (2007), Grove and Wu (2007), Hilmer and Hilmer (2007) and Krueger and Wu (2000).

A different line of literature has been concerned with the identification of policies that can promote research excellence. Part of this literature is motivated by the low European research performance in economics when compared to the USA. Such studies invariably emphasize the relevance of incentives, both at individual and department levels, and the need to promote profound institutional reforms in most European countries (see for example Drèze and Estevan, 2007).

This study considers these two lines of literature, assessing the role of two different types of determinants of research performance of recent $\mathrm{PhD}$ graduates: the quality of the academic training received versus the institutional setting of the job placement institution upon completion of the $\mathrm{PhD}$. Analyzing the productivity of $\mathrm{PhD}$ graduates by taking into consideration only their academic background seems an incomplete view, given the literature on the relevance of the institutional setting and career incentives for the promotion of research quality. Anecdotal evidence can illustrate this point: two equally students talented receiving their $\mathrm{PhD}$ degree from the same institution and at the same time, often perform subsequently quite differently in terms of research output, depending on the country or institution where they are placed and the conditions 
inducing or hindering quality research. Smeets, Warzynski and Coupé (2006) is among the few studies we could find that consider the interaction of these two factors when studying the research productivity of recent economics $\mathrm{PhD}$ graduates.

We concentrate on $\mathrm{PhD}$ graduates in labor economics who received their degree in 2000 to 2005, from a European or USA university. Identification of the population under study relied on two sources: Dissertations Abstracts, a database covering every dissertation defended at an American accredited institution, at fifty British and a few other European institutions; the files of the IZA European Summer in Labor Economics, containing detailed information on both successful and unsuccessful applicants from all over Europe. Research productivity is evaluated alternatively as the raw number of publications or the quality-adjusted number of publications of an individual.

Section 2 overviews the literature that has dealt with the comparison of research productivity in Europe and the USA. Section 3 places labor economics in the framework of the overall economics field. Section 4 provides a detailed description of the dataset and section 5 presents descriptive statistics. The model under estimation is presented in section 6 and its results are discussed. Section 7 concludes.

\section{European versus North-American Research Productivity}

The higher research productivity of American economists when compared to Europeans has been widely acknowledged, as reported in the special issue of the Journal of the European Economic Association dedicated to ranking European institutions by research in economics and comparing them with the USA. "The studies [...] paint a well-known but distressing picture of relatively inferior performance in Europe" (Neary, Mirrlees and Tirole, 2003: 1248). Much earlier, in an article that launched wide debate, Portes had referred to the "overwhelming American 
dominance" (Portes, 1987: 1332). Kirman and Dahl refer to "America's lead" (Kirman and Dahl, 1994: 509). More recently, this difference has been highlighted by Drèze and Estevan (2007).

The sources of this productivity gap have been subject to debate. Neary and co-authors mention the "poor governance of most European universities and the limited role given to research criteria in their funding" (Neary, Mirrlees and Tirole, 2003: 1248). Frey and Eichenberger (1993) argue that the market constraints are different across both sides of the Atlantic, as the USA is a wide and competitive market where there is consensus judgment over scientific performance, while, on the contrary, Europe is fragmented along national noncompetitive markets. Kocher, Luptacik and Sutter (2006) check the efficiency of research in economics in several OECD countries, concluding that countries such as Ireland, the Netherlands, Belgium or Norway show an efficient relation between inputs and output, and exhibit increasing returns to scale, and would thus gain from an increase in their scale of activity. Some authors highlight strong points specific to Europe, which render it apart from the American model: Kirman and Dahl (1994) refer to the analysis of economic problems of particular concern to Europe; Frey and Eichenberger (1993) underline the political influence traditionally enjoyed by European academics.

The European Economic Association has clustered concerns and the discussion over policies to reorganize and fund research in Europe, so as to catch up with American standards of performance. A project launched in 1999 aimed specifically at evaluating economics research, and the publication of its results in 2003 opened a wide debate over policy options. Drèze and Estevan (2007) present a range of policy measures for Europe: the adoption of English as the common language for publishing and graduate teaching; scaling up the size of $\mathrm{PhD}$ programs; and reforming institutions, in particular with the introduction of research incentives and block grants for efficient $\mathrm{PhD}$ programs and for most productive young academics. Portes (1987) places 
great emphasis on collaboration, concentration, labor mobility and career incentives based on competence.

Most analyses, in particular from the European side, expect Europe to move towards American standards of research productivity (see the overview in Borghans and Coervers, 2008). This would be brought about by the on-going economic and cultural integration with the market widening and becoming more transparent, despite an increasing push for regionalization that could impose language and other barriers on growing scientific mobility (Frey and Eichenberger, 1993). Efforts to reorganize and fund research are underway by the European Union, which are aimed at promoting mobility, cross-country cooperation and excellence more broadly. A new generation of economists in Europe is believed to be growing, equipped with the analytic tools and motivation to place European research at a higher level (Kirman and Dahl, 1994).

This study analyzes precisely a new generation of economists in one particular field, labor economics. Before progressing, we check whether labor economics can be considered representative of overall economics concerning the pattern and trends over the last few decades in research productivity in Europe compared to the USA.

\section{Labor versus other Fields in Economics}

By all accounts, the Econlit database is the most comprehensive database of economics-related journals. Published by the American Economic Association, the Econlit indexes an increasing number of journals from all over the world, most of them in English. While the database includes articles published in journals going all the way back to 1969, the scope of information has changed over time. Author affiliations were not added until the mid-eighties and the classification system for economic articles (JEL codes) was modified in 1991. Since we want to quantify the scientific production in labor economics and compare the USA to Europe, we restricted our 
analysis to the period spanning 1991 through 2006. Overall, our final sample consisted of 304,413 Econlit articles. $^{2}$ We classified articles in the 19 primary JEL categories using the first JEL code assigned to the article. With a share of 8.6 percent, the primary category " $\mathrm{J}$ - Labor and Demographic Economics" is the third largest one in terms of number of articles. When quality weights are applied to articles using the metric of Kalatzidakis, Mamuneas and Stengos (2003) (henceforth KMS) the share of labor articles increases slightly to 9.4 percent. $^{3}$ As Figure 1 shows, the shares of labor articles have oscillated over time, but remained relatively stable throughout the period regardless of the metric used. ${ }^{4}$

Because our interest is in the USA/Europe contrast we used information on author affiliation to assign a country of origin to each author. We only considered the first affiliation reported by each author, and discarded articles lacking information that permitted identification of the authors' country of origin. The value of each article was divided by the number of authors and the production of the USA and Europe was computed by tallying up all the shares. ${ }^{5}$

Labor economics seems to represent well both the pattern and the trend in scientific productivity in Europe versus the USA. Both Figures 2 and 3 show the European contribution to be more relevant when considering the raw number of articles than when weighting the articles by the quality of the journal. In other words, the European strategy seems, so far, to bet more on quantity. Both graphs also reveal a remarkable upward trend in the European contribution to scientific output captured in Econlit. Indeed, around the turn of the century Europeans surpassed the USA in the number of articles contributed. This might have been brought about by two different factors: on the one hand, the research output in Europe is undoubtedly increasing; on the

\footnotetext{
${ }^{2}$ The data was compiled from 3 different CDs (88-Jun03, 02-Jun06, and 06-Mar08). In the case of duplicates we removed the oldest record. We corrected several data inconsistencies and typos and adopted a strict definition of journal article (i.e. we dropped Editor's notes, book reviews, comments, data tables, messages, prefaces, errata, obituaries, forewords, etc).

${ }^{3}$ In Appendix B we show the distribution of articles for all JEL codes.

${ }^{4}$ The exception is the last year of 2006 where there seems to be a drop in both shares.

${ }^{5}$ To illustrate, the present article would contribute $2 / 3$ to Europe and 1/3 to the USA.
} 
other, Econlit has been covering an increasing number of journals, and the share of Europe-based journals has increased.

This section has shown that the findings in this study on labor economics can indeed be representative of the more general situation in economics. Its relevance for policy purposes is therefore strengthened.

\section{Dataset}

The population under study consists of labor economics $\mathrm{PhD}$ graduates who got their degree in the years 2000 to 2005 in Europe or the USA. Identification of the population under study relied on two different sources: Dissertation Abstracts Online and the files of applicants to the IZA European Summer School in Labor Economics.

\section{Data on PhD graduates}

Dissertation Abstracts covers dissertations defended at all accredited American institutions, at 50 British institutions and a few other European ones. It is produced by ProQuest Information and Learning and it is based on information that each degree-granting institution supplies to University Microfilms International. The reported variables include: name of graduate, type of degree obtained, awarding institution, country, year of defense, supervisor's name, thesis title, subject, keywords and abstract. The following constraints were imposed for the data selection: thesis defended in 2000 to 2005 in the USA or Europe whose first subject code was "labor economics", leading to the degree "PhD" or equivalent. ${ }^{6}$ This procedure allowed us to identify a total of 650 individuals, 47 of which were from European institutions.

\footnotetext{
${ }^{6}$ The Dissertation Abstracts database has no standardized way to designate the degree awarded. Non-USA institutions tend to use their own designation for the type of degree awarded. We considered the following list of designations for degree awarded as equivalent to "PhD”: "Dr.", "D.Soc.Sc.", "Fil.dr.", "PD”, ”Dr.Ec.", "Dr.Econ”, "Dr.Soc.Sc." and "Ekon. dr".
} 
The IZA European Summer School in Labor Economics has been organized annually since 1988 by the Institute for the Study of Labor (IZA Bonn) as a one-week event that includes a set of lectures by two renowned senior researchers, and presentations and discussions by $\mathrm{PhD}$ students. The event counts on the institutional support of major scientific associations in Europe: European Economic Association (EEA), Centre for Economic Policy Research (CEPR), European Association of Labour Economists (EALE), and European Society for Population Economics (ESPE). From 2004 to 2007, it was funded by the European Commission under its Sixth Framework Programme, Marie Curie Conferences and Training Courses. Throughout the period it has been running all expenses incurred by the PhD students to attend the event were fully covered (traveling costs, accommodation and meals, visa fees if required, and other costs such as printing of posters for presentation). About 35 students are selected to participate each year and, until very recently (2003), only students at European universities were eligible to apply. Given the reputation of the event and the fact that participation imposes no financial burden at all on the participants or their institutions, a very large pool of applicants was attracted each year, with the chances of getting accepted currently standing at 0.25 .

Combining the IZA files on both participants and unsuccessful applicants during the tenyear period 1998 to 2007, we detailed data on 796 individuals, thus covering a substantial share of labor economics $\mathrm{PhD}$ students at European universities. Reported data include: name of the student, gender, nationality, $\mathrm{PhD}$ institution, country, supervisor's name, title of paper presented, abstract, year of $\mathrm{PhD}$ commencement, contact information, as well as his/her resume at the time of application. Further data on the Summer School applicants was collected via web searches to retrieve their date of completion of $\mathrm{PhD}$. Individuals who were awarded the degree in 2000 to 
2005 at a European or US institution were used for analysis. Data on 197 individuals was thus kept. $^{7}$

Further data collection for all individuals under analysis took place from November 2007 to July 2008 using the web to search for the following variables: employing institution, country, job title, year of job commencement, email address, gender, year of birth, nationality and, whenever feasible, resume. An email inquiry was addressed in August 2008 to 510 individuals for whom the nationality, date of birth or gender was missing. A high reply rate of $41 \%$ was achieved with 204 replies.

Additionally, the publication record for all selected individuals, as well as from their $\mathrm{PhD}$ supervisors, was retrieved from Econlit. We only considered journal articles and notes (editorials, comments, etc were excluded). For the graduates we collected all publications in the period ranging between 2 years before award of the degree and the limit year of 2006. For all supervisors we collected their publications between 1988 and 2006.

\section{Measuring research productivity}

The research productivity of recent $\mathrm{PhD}$ graduates and their supervisors was measured by

- the number of journal articles captured in Econlit, and

- the number of journal articles weighted by the quality of the journal (according to KMS), deflated by the number of authors.

Finally, measures of quality of the institution awarding the $\mathrm{PhD}$ and the employing institution were used in the analysis to define the top institutions in the USA and in Europe. We relied on three alternative universal rankings of institutions included in the Journal of the European Economic Association: Coupé (2003: 1316-1317), which is based on the number of citations;

\footnotetext{
${ }^{7}$ Note that the Summer School is open strictly for researchers not yet holding the $\mathrm{PhD}$ and therefore many applicants cannot possibly fulfill the conditions to be included in the sample (namely, all the applicants in 2007 and 2006, virtually all of those in 2005, and several from earlier periods).
} 
Coupé (2003: 1326-1327), which is based on the number of publications; and KMS (2003: 1357). We classified an institution as "top-10" in the USA (or Europe) if the institution was ranked in the "top-10" USA (or Europe) institutions for at least two of those three rankings. ${ }^{8}$

\section{Descriptive Statistics}

The database includes 847 graduates (237 from European institutions and 610 from American institutions). Within Europe, a wide set of countries is covered. ${ }^{9}$ The distribution of graduates by gender, year of defense, region of work, type of job held afterwards and type of employer is reported separately in Table 1 for graduates from the USA and Europe. As we can see, the gender distribution is similar across the two groups. The European sample has a slightly higher share of recent $\mathrm{PhDs}$. More than half of the European graduates (82\%) stayed to work in Europe, whereas $62 \%$ of the graduates in the USA stayed to work there. A larger share of American graduates holds a Professorship (possibly related to the differences in the date of defense), which is compensated by a larger proportion of European graduates holding a Researcher position. Finally, the distribution according to the type of employer is similar across the two groups with the largest share (over half) placed at universities.

The distribution of graduates by gender, year of defense, region of work, type of job held afterwards and type of employer, is reported in table 1, separately for graduates from the USA and Europe. As we can see the gender distribution is similar across the two groups. The European sample has a slightly higher share of recent PhDs. More than half of the European graduates $(82 \%)$ stayed working in Europe, whereas $62 \%$ of the graduates in the USA stayed working there.

\footnotetext{
8 Thus coding as top USA institutions Harvard, Chicago, Pennsylvania, Stanford, MIT, California-Berkeley, Northwestern, Yale, Michigan, and Princeton, and as top European institutions the London School of Economics, Oxford, Cambridge, Tel Aviv U, U College London, Hebrew U, Tilburg, Warwick, and U Amsterdam.

${ }^{9}$ The distribution of graduates across countries was the following: Austria (2), Belgium (12), Czech Republic (3), Denmark (8), Finland (8), France (17), Germany (41), Hungary (1), Israel (1), Italy (17), Netherlands (15), Poland (2), Portugal (1), Romania (1), Spain (15), Sweden (27), Switzerland (7), UK (59), USA (610).
} 
A larger share of American graduates holds a Professorship (possibly related to the differences in the date of defense), which is compensated by a larger proportion of European graduates holding a Researcher position. Finally, the distribution according to type of employer is similar across the two groups with the largest share (over half) placed in universities.

Interesting differences in research productivity emerge between the two groups. European graduates publish on average more than twice the number of articles than their USA counterparts (Table 2), which is partly due to the larger share of graduates in the USA who have not (yet) published any article (Figure 4). The actual difference in terms of the number of articles may be even larger because the Econlit has a known "anglophone bias", in the sense that publications in English journals are over-represented in the database.

However, once the quality of the journal is taken into account, this difference vanishes. When we measure productivity using the KMS quality-weighted measure the results are then reversed and USA graduates reveal a higher average productivity (Table 2). Restricting the sample to just those authors who have published shows a clearer pattern -European graduates publish on average more articles, but in journals of lower average quality (Table 3).

The evidence so far reported confirms to a large extent the general pattern often highlighted of lower average research productivity in Europe than in the USA. We are, however, aggregating over a very broad and heterogeneous set of institutions. Averages may be a misleading concept to compare regions known to encompass top tier as well as lower quality institutions. The analysis below aims at going beyond this broad view.

\section{Research Performance of American and European Graduates}

In this section we contrast the performance of European and American graduates using regression analysis. As a first step we employed Poisson regressions using the total number of Econlit 
publications as the dependent variable. Among the independent variables we considered characteristics of the graduate (gender and time since completion of $\mathrm{PhD}$ ), the quality of the academic training received (the type of institution awarding the $\mathrm{PhD}$ and the research productivity of the supervisor), and the characteristics of the institution where the graduate was placed. A list of all right-hand side variables and respective description is shown in Table 4 below.

In Table 5 we present our first set of results. With the exception of the year 2 dummy, all variables in the first specification, Column 1, are statistically significant at the usual significance levels. ${ }^{10}$ In line with the results of Hilmer and Hilmer (2007) we also observe that female graduates exhibit lower productivity than their male counterparts. As expected, the type of institution where the individual is placed has a significant impact on his/her performance. Everything else constant, graduates placed at a university or research center publish about 80 percent more articles than graduates placed at other institutions. The productivity of the supervisor seems to be another important factor when explaining academic productivity. The results also confirm one of the most striking findings of the previous section; even when controlling for multiple factors, there seems to be clear evidence that graduates from European universities publish more than graduates from American universities.

Anecdotal evidence suggests that students graduating from tier 1 universities are the more prolific researchers. ${ }^{11}$ Hence, in a second specification (Column 2) we introduced two additional variables that identify whether or not the students graduated from a "top-10" American or "top10" European university in the field. Neither of these two variables is significant. Column 3 shows a regression where we consider the location of the institution of placement. Whether the institution of placement is located in Europe or the USA seems to have a similar effect. However,

\footnotetext{
${ }^{10}$ All regression tables report the more conservative "Huber/White robust" standard errors.

${ }^{11}$ Indirect evidence is provided by Amir and Knauff (2008). The authors report that only $20 \%$ of faculty hired at the top ten economics departments of the USA comes from outside of that group.
} 
placement at institutions outside of Europe or the USA impacts negatively on productivity. Finally, in Column 4 we added two more variables that identify whether or not the graduates were placed at any of the top 10 institutions. The argument can be made that top institutions select the most productive researchers and provide the best conditions and incentives for research. However, as the results in Table 5 show, none of the variables identifying top institutions seem to be associated with early-career success as measured by the number of articles.

At this point we should emphasize that the results of our regressions need to be interpreted with care. We uncover relationships between the productivity of graduates and other variables, but we cannot assume the existence of causal relationships. For example, we earlier stated that everything else constant, a graduate placed at a research institution will publish around 80 percent more. But that does not mean that if we were to switch a recently placed student from say, a private company to a research institution, we would expect an 80 percent increase in productivity. Most likely there was some selection process at work and the more academically inclined students tended to favor placement at research institutions.

Another important caveat of our analysis has to do with our data collection procedures. As discussed earlier, data from US doctoral students were collected in a systematic manner, while for most Europeans the data came from the IZA files of Summer School applicants. Thus, it may be argued that the European data is biased because the sample composition may not be representative of the relevant graduating institutions in Europe, or because applicants to the IZA Summer School are more likely to be those willing to pursue a research oriented career. To shed some light into this issue we reestimated the model by restricting the sample to graduates placed at academic institutions (Columns 6 through 10 in Table 5). As we can see the results are remarkably stable across samples suggesting that the effect of any bias, if it exists, is negligible. 
The measure of productivity used so far does not account for quality. Hence, in Table 6 we introduce a quality-adjusted metrics for productivity, estimating linear regression models where the dependent variable is the KMS based quality-weighted measure of publications. The results change considerably. Most notably, the clear difference between the productivity of graduates from American and European universities practically disappears. Similarly, graduation from a top institution (in the US or Europe) does not seem to have an impact on the quality of the research output. In terms of institution of placement we also observe significant changes. Now it seems that working in the USA is associated with an increase in productivity. That increase is even higher if the graduate is placed at one of the top 10 American institutions.

Also in contrast with the results on the number of publications, we find no significant differences between males and females once the research output is measured in terms of quality. The estimated coefficients on the number of years since completion of the $\mathrm{PhD}$ indicate that quality takes longer to come out than quantity. Whereas in the case of quantity a significant coefficient is estimated for year 3 and later, for quality of outputs such coefficients are not significantly different from zero until year 4.

Our results show that either the institutional setting at top-10 institutions in the USA works better at providing incentives and putting pressure for high quality outputs, or that these institutions are able to attract the very best researchers. In the latter case, it leads to the question as to why European institutions are not able to select that type of researchers. One obvious reason would be money: European institutions may be constrained by national legislation setting flat salary scales; but they may as well be constrained in their ability to provide non-monetary incentives as well if they have lower flexibility to manage, for example, teaching times or administration duties. 
We further aimed at checking the contribution of different groups of nationalities to the productivity of American institutions. As such, we interacted the dummy variable "works in USA" with the variable "European nationality" or "other nationality" (leaving the American nationality as the omitted category); similarly, we interacted the variable "works in top-10 USA" with those same dummies for groups of nationalities. We find no significant differences between the productivity of the different nationalities working in the USA. To the extent that those working in American institutions, and in particular top institutions, are in general more productive than those working in Europe, we find some support for the often stated claim that the USA is attracting the best Europeans in a brain drain type of flow. ${ }^{12}$

\section{Conclusions}

We have analyzed differences in research productivity of recent $\mathrm{PhD}$ graduates from European and USA universities. The received wisdom is that research based in the USA dominates in quantity and quality. We find that this is no longer true at this simplistic level. At first sight it even seems that European graduates are the more productive. However, once we account for the quality of scientific journals, we find that differences between graduates from American and European institutions vanish. In terms of output quality, results indicate that graduates placed at American institutions, in particular top ones, are likely to publish more quality-adjusted articles than their European counterparts.

This may be because, when hired by a top-USA institution, graduates already have several good acceptances or because of more focused research efforts and clearer career incentives. This could also be because the American-based institutions still provide a better academic

\footnotetext{
${ }^{12}$ It is often claimed that authors based in Europe have more difficulties getting their work accepted in American-based journals. Hamermesh (2002) discusses this issue specifically for labor economics and Oswald (2008) provides a recent view, but both doubt the "discrimination" hypothesis.
} 
environment to reach the standard leading journals which are still closer attached to the USA. Another explanation is that the rising quantity and the increased visibility the European researchers have provided over recent years needs more time to breed even more quality research and lead to high quality journal publications. Part of this is related to the fact that the very many new European-based journals where Europeans publish more than proportionally need many more years to move up the quality ladder in international competition.

Publication strategies also seem to differ across both continents. In the USA, PhD graduates aim at a decent number of articles in "A-journals" before the tenure decision; the probability of acceptance in those journals is low, and hence delays to acceptance and publication of papers are longer. In Europe, young researchers often publish before defending their $\mathrm{PhD}$; journals are not necessarily A-ranked; and the rank of the journals (although of rising importance) is not yet so crucial for the tenure decision, which follows often other rules.

In terms of policy conclusions there is still a "clear need to develop a coherent strategy to improve doctoral training in economics Europe" that would "counteract the strong tendency for the best European economists and students to gravitate towards that country [the USA]" (Kirman and Dahl, 1994: 520). Drèze and Estevan (2006) had similarly mentioned the "brain drain", as the USA manages to retain its brains and attract foreign ones, stressing the role played in this process by its $\mathrm{PhD}$ programs. While there seems still much to do to improve the academic incentives in European $\mathrm{PhD}$ programs, the success in the catching-up process in the past decades is encouraging. 


\section{References}

Amir, Rabah and Malgorzata Knauff (2008) "Ranking Economics Departments Worldwide on the Basis of PhD Placement", Review of Economics and Statistics, 90(1): 185-190.

Athey, Susan, Lawrence F. Katz, Alan B. Krueger, Steven Levitt, and James Poterba (2007) "What Does Performance in Graduate School Predict? Graduate Economics Education and Student Outcomes", American Economic Review, 97(2): 512-18.

Barrett, Christopher B., Aliakbar Olia, and Dee von Bailey (2000) "Subdiscipline-specific Journal Rankings: Whither Applied Economics?", Applied Economics, 32: 239-252.

Borghans, Lex and Frank Coervers (2008) "Mobility and the Changing Structure of Research and Higher Education in Europe", NBER Conference "American Universities in a Global Market", October 2-4, Woodstock, Vermont, USA.

Coupé, Tom (2003) "Revealed Performances: Worldwide Rankings of Economists and Economics Departments, 1990-2000", Journal of the European Economic Association, 1(6): 1309-45.

Drèze, Jacques H. and Fernanda Estevan (2007) "Research and Higher Education in Economics: Can We Deliver the Lisbon Objectives?", Journal of the European Economic Association, 5(2-3): 271-304.

Ehrenberg, Ronald G. and Panagiotis G. Mavros (1995) "Do Doctoral Students' Financial Support Patterns Affect Their Times-to-Degree and Completion Probabilities?", Journal of Human Resources, 30(3): 581-609.

Frey, Bruno and Reiner Eichenberger (1993) "American and European Economics and Economists", Journal of Economic Perspectives, 7(4): 185-193.

Grove, Wayne A. and Stephen Wu (2007) "The Search for Economics Talent: Doctoral Completion and Research Productivity”, American Economic Review, 97(2): 506-511.

Hamermesh, Daniel H. (2002) "Presidential Address to the Society of Labor Economists, Austin, Texas, April 20, 2001”, Journal of Labor Economics, 20(4): 709-732.

Hilmer, Christiana and Michael Hilmer (2007) "Women Helping Women, Men Helping Women? Same-Gender Mentoring, Initial Job Placements, and Early Career Publishing Success for Economics PhDs", American Economic Review, 97(2): 422-426.

Kalaitzidakis, Pantelis, Theofanis P. Mamuneas, and Thanasis Stengos (1999) "European Economics: An Analysis Based on Publications in the Core Journals", European Economic Review, 43: 1150-1168.

Kalaitzidakis, Pantelis, Theofanis P. Mamuneas, and Thanasis Stengos (2003) "Rankings of Academic Journals and Institutions in Economics." Journal of the European Economic Association, 1(6): 1346-1366.

Kirman, Alan and Mogens Dahl (1994) "Economic Research in Europe", European Economic Review, 38: 505-522. 
Kocher, Martin G., Mikulas Luptacik, and Matthias Sutter (2006) "Measuring Productivity of Research in Economics: A Cross-country Study using DEA", Socio-Economic Planning Sciences, 40: 314-332.

Krueger, Alan B. and Stephen Wu (2000) "Forecasting Job Placements of Economics Graduate Students", Journal of Economic Education, 31(1): 81-94.

Laband, David N. and Michael J. Piette (1994) "The Relative Impacts of Economics Journals: 1970-1990”, Journal of Economic Literature, 32(2): 640-666.

Oswald, Andrew J. (2008) "Can we Test for Bias in Scientific Peer-review?" IZA discussion paper 3665. Bonn: Institute for the Study of Labor.

Neary, Peter J., James A. Mirrlees, and Jean Tirole (2003) "Evaluating Economics Research in Europe: an Introduction”, Journal of the European Economic Association, 1(6): 1239-1249.

Portes, Richard (1987) “Economics in Europe”, European Economic Review, 31: 1329-1340.

Roessler, Christian (2004) Econphd Rankings. http://www.econphd.net, accessed May 11, 2008.

Scott, Loren C. and Peter M. Mitias (1996) "Trends in Rankings of Economics Departments in the U.S.: An Update", Economic Inquiry, 34(2): 378-400.

Smeets, Valérie, Frédéric Warzynski, and Tom Coupé (2006) "Does the Academic Labor Market Initially Allocate New Graduates Efficiently?" Journal of Economic Perspectives, 20(3): $161-172$.

UNESCO [United Nations Educational, Scientific and Cultural Organization] (2008) http://erc.unesco.org/cp/MSList.asp?lg=E\&\&type=1\&®=1, accessed August 17, 2008. 
Figure 1 - Scientific Production in Labor and Demographic Economics as a Share of Economics in General

Scientific Production in Labor Economics and Demographics

Share of Total Number of Articles in Econlit

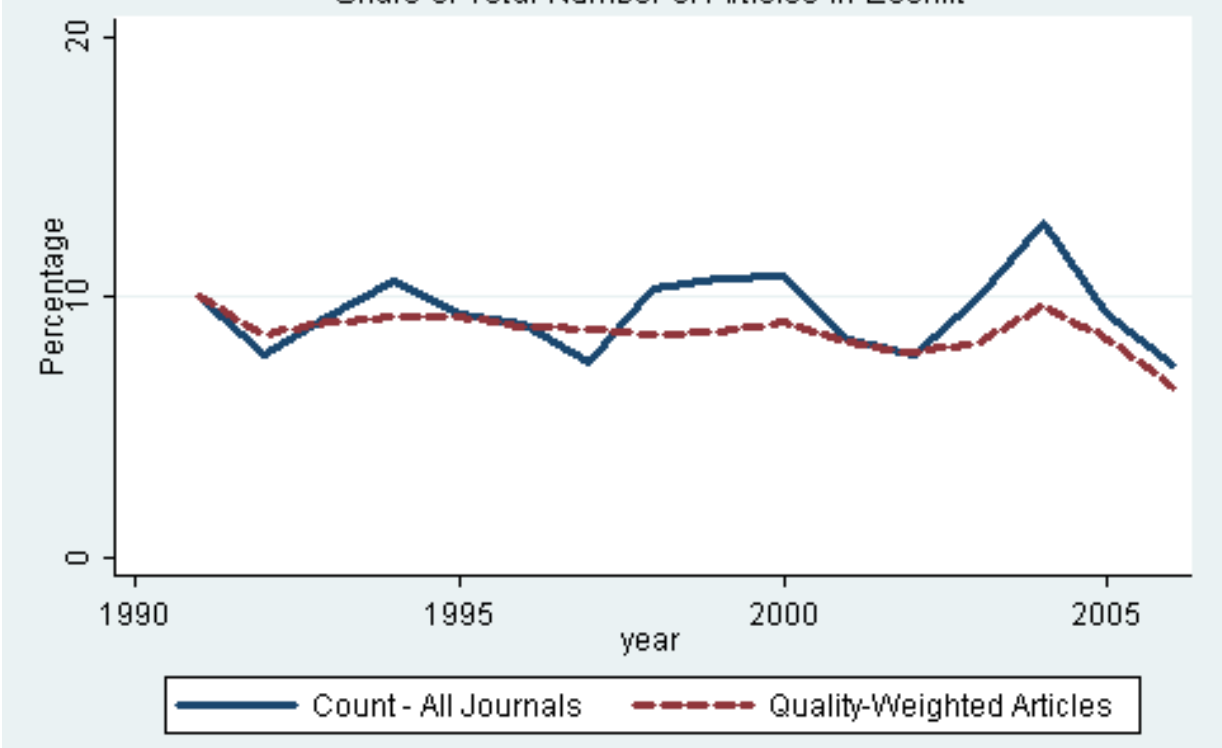


Figure 2 - Scientific Production in Europe versus the USA: Economics in General

Total Production in Economics

Ratio of Econlit Articles in Europe over USA

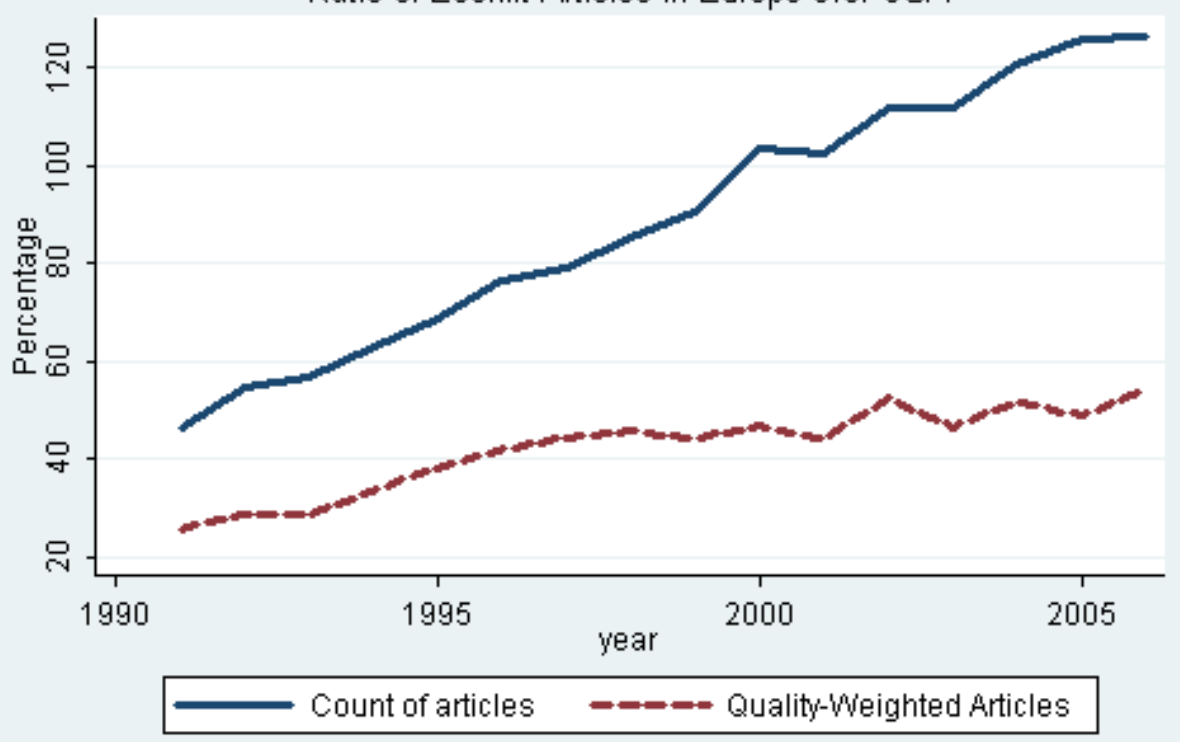


Figure 3 - Scientific Production in Europe versus the USA: Labor and Demographic Economics

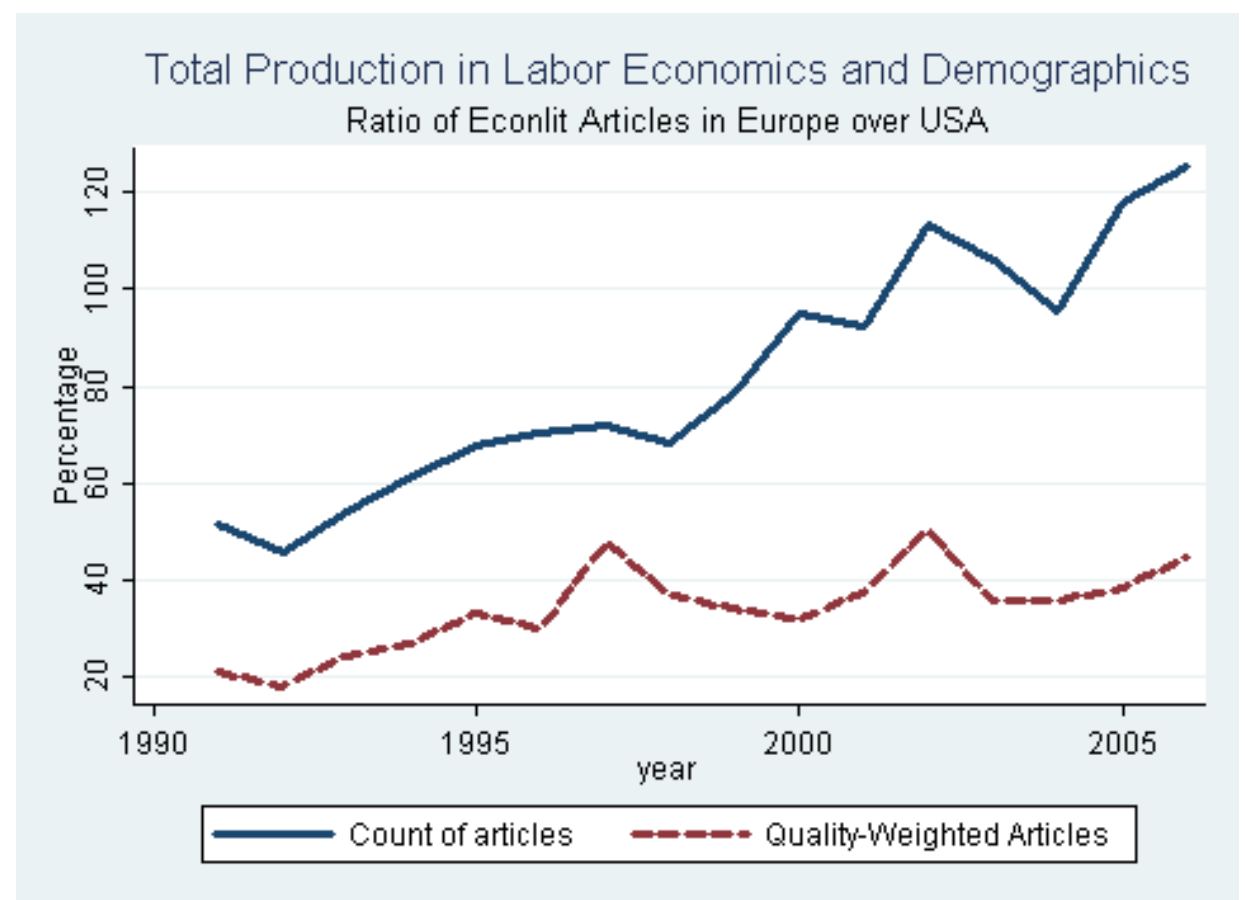


Figure 4 - Number of Publications, Europe versus USA Graduates

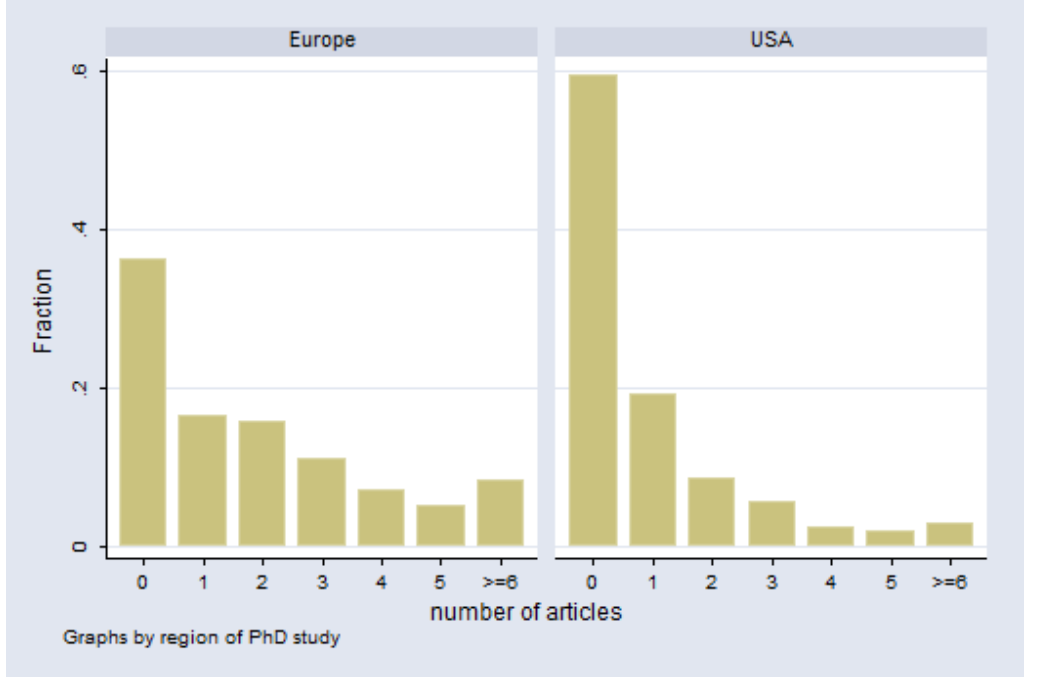


Table 1 - Distribution of Graduates from USA and European Universities (\%)

\begin{tabular}{|c|c|c|c|}
\hline & \multicolumn{3}{|c|}{ Region of PhD study } \\
\hline & Europe & USA & Total \\
\hline \multicolumn{4}{|l|}{ Gender } \\
\hline Male & 57.38 & 55.74 & 56.2 \\
\hline Female & 42.62 & 40.16 & 40.85 \\
\hline missing & 0 & 4.1 & 2.95 \\
\hline \multicolumn{4}{|l|}{ Year of defense } \\
\hline 2000 & 10.97 & 18.03 & 16.06 \\
\hline 2001 & 16.03 & 16.23 & 16.17 \\
\hline 2002 & 18.14 & 14.59 & 15.58 \\
\hline 2003 & 17.72 & 15.08 & 15.82 \\
\hline 2004 & 20.68 & 18.36 & 19.01 \\
\hline 2005 & 16.46 & 17.7 & 17.36 \\
\hline \multicolumn{4}{|l|}{ Region of work } \\
\hline Europe & 82.28 & 3.44 & 25.5 \\
\hline USA & 2.95 & 62.46 & 45.81 \\
\hline Other & 3.8 & 16.89 & 13.22 \\
\hline missing & 10.97 & 17.21 & 15.47 \\
\hline \multicolumn{4}{|l|}{ Type of job } \\
\hline Professor & 27.85 & 44.26 & 39.67 \\
\hline Lecturer/Reader/Instr & 11.81 & 4.59 & 6.61 \\
\hline Researcher & 41.77 & 23.28 & 28.45 \\
\hline Consultant & 1.27 & 3.93 & 3.19 \\
\hline Other & 3.8 & 2.13 & 2.6 \\
\hline missing & 13.5 & 21.8 & 19.48 \\
\hline \multicolumn{4}{|l|}{ Type of employer } \\
\hline University & 62.03 & 55.90 & 57.62 \\
\hline Research Center & 13.08 & 5.41 & 7.56 \\
\hline Central/Federal Bank & 2.95 & 3.11 & 3.07 \\
\hline Interntl Org/Gov Dept & 10.13 & 12.30 & 11.69 \\
\hline Consulting Firm & 0 & 5.08 & 3.66 \\
\hline Other Private Sector & 0.84 & 1.15 & 1.06 \\
\hline missing & 10.97 & 17.05 & 15.35 \\
\hline
\end{tabular}


Table 2 - Research Productivity, Europe versus USA Graduates

\begin{tabular}{|r|r|r|r|}
\hline \multirow{2}{*}{ Region of PhD study } & \multicolumn{3}{|c|}{ Summary of } \\
& & \multicolumn{3}{|c|}{ number of Econlit articles } \\
\cline { 3 - 5 } & Mean & Std. Dev. & Freq. \\
\hline Europe & 2.017 & 2.436 & 237 \\
USA & 0.962 & 1.789 & 610 \\
Total & 1.257 & 2.045 & 847 \\
\hline
\end{tabular}

\begin{tabular}{|r|r|r|r|}
\hline & \multicolumn{3}{|c|}{ Summary of } \\
& \multicolumn{3}{|c|}{ quality-weighted articles (KMS criterion) } \\
\cline { 2 - 4 } & Mean & Std. Dev. & Freq. \\
\hline Europe & 4.690 & 12.170 & 237 \\
USA & 7.907 & 29.757 & 610 \\
Total & 7.006 & 26.093 & 847 \\
\hline
\end{tabular}


Table 3 - Research Productivity, Europe versus USA Graduates (only Graduates who have Published)

\begin{tabular}{|r|r|r|r|}
\hline \multirow{2}{*}{ Region of PhD study } & \multicolumn{3}{|c|}{ Summary of } \\
& & \multicolumn{3}{|c|}{ number of Econlit articles } \\
\cline { 3 - 5 } & Mean & Std. Dev. & Freq. \\
\hline Europe & 3.166 & 2.381 & 151 \\
USA & 2.377 & 2.131 & 247 \\
Total & 2.676 & 2.260 & 398 \\
\hline
\end{tabular}

\begin{tabular}{|r|r|r|r|}
\hline & \multicolumn{3}{|c|}{ Summary of } \\
& \multicolumn{3}{|c|}{ quality-weighted articles (KMS criterion) } \\
\cline { 2 - 4 } & Mean & Std. Dev. & Freq. \\
\hline Europe & 7.360 & 14.603 & 151 \\
USA & 19.526 & 44.321 & 247 \\
Total & 14.911 & 36.506 & 398 \\
\hline
\end{tabular}


Table 4 - List of Independent Variables

\begin{tabular}{ll}
\hline Variable & Description \\
\hline Year $i, i=2, \ldots, 6$ & 1 if the PhD was completed $i$ years ago \\
\hline Female & 1 if female \\
\hline ResJob & 1 if employed by a University or Research Center \\
\hline PhDUSA & 1 if the PhD is from an institution in the USA \\
\hline WrkUSA & 1 if placement is at an institution in the USA \\
\hline WrkEUR & 1 if placement is at an European institution \\
\hline ProdSup & KMS quality-weighted publications of the main supervisor / 100 \\
\hline PhDT10USA & 1 if the PhD was obtained from a top 10 university in the USA \\
\hline PhDT10EUR & 1 if the PhD was obtained from a European top 10 university \\
\hline WrkT10USA & 1 if the job is at a top 10 university in the USA \\
\hline $\begin{array}{l}\text { WrkT10EUR } \\
\text { Note: Whilst we only have PhD issuing universities from the USA and Europe (dummy variable for the USA), the } \\
\text { job placement can be in any country of the world (dummy variables for the USA and for Europe, with the rest of the } \\
\text { world as the omitted category). }\end{array}$
\end{tabular}


Table 5 - Number of Publications (Poisson Regression Models)

\begin{tabular}{|c|c|c|c|c|c|c|c|c|c|c|}
\hline & \multicolumn{5}{|c|}{ Graduates from all universities } & \multicolumn{5}{|c|}{ Graduates placed at academic institutions } \\
\hline & (1) & (2) & (3) & (4) & (5) & (6) & (7) & (8) & (9) & (10) \\
\hline Year 2 & $\begin{array}{r}0.32 \\
{[1.43]}\end{array}$ & $\begin{array}{r}0.30 \\
{[1.36]}\end{array}$ & $\begin{array}{r}0.31 \\
{[1.41]}\end{array}$ & $\begin{array}{r}0.31 \\
{[1.41]}\end{array}$ & $\begin{array}{r}0.30 \\
{[1.34]}\end{array}$ & $\begin{array}{r}0.32 \\
{[1.37]}\end{array}$ & $\begin{array}{r}0.30 \\
{[1.27]}\end{array}$ & $\begin{array}{r}0.32 \\
{[1.34]}\end{array}$ & $\begin{array}{r}0.32 \\
{[1.34]}\end{array}$ & $\begin{array}{r}0.29 \\
{[1.21]}\end{array}$ \\
\hline Year 3 & $\begin{array}{r}0.78 \\
{[4.05]}\end{array}$ & $\begin{array}{r}0.77 \\
{[3.99]}\end{array}$ & $\begin{array}{r}0.77 \\
{[4.06]}\end{array}$ & $\begin{array}{r}0.76 \\
{[4.05]}\end{array}$ & $\begin{array}{r}0.76 \\
{[4.05]}\end{array}$ & $\begin{array}{r}0.82 \\
{[4.24]}\end{array}$ & $\begin{array}{r}0.82 \\
{[4.19]}\end{array}$ & $\begin{array}{r}0.81 \\
{[4.22]}\end{array}$ & $\begin{array}{r}0.81 \\
{[4.21]}\end{array}$ & $\begin{array}{r}0.80 \\
{[4.17]}\end{array}$ \\
\hline Year 4 & $\begin{array}{r}1.07 \\
{[5.59]}\end{array}$ & $\begin{array}{r}1.03 \\
{[5.38]}\end{array}$ & $\begin{array}{r}1.03 \\
{[5.40]}\end{array}$ & $\begin{array}{r}1.02 \\
{[5.31]}\end{array}$ & $\begin{array}{r}1.00 \\
{[5.15]}\end{array}$ & $\begin{array}{r}1.22 \\
{[6.30]}\end{array}$ & $\begin{array}{r}1.17 \\
{[5.97]}\end{array}$ & $\begin{array}{r}1.18 \\
{[6.05]}\end{array}$ & $\begin{array}{r}1.17 \\
{[5.97]}\end{array}$ & $\begin{array}{r}1.14 \\
{[5.80]}\end{array}$ \\
\hline Year 5 & $\begin{array}{r}1.17 \\
{[6.14]}\end{array}$ & $\begin{array}{r}1.14 \\
{[5.97]}\end{array}$ & $\begin{array}{r}1.16 \\
{[6.11]}\end{array}$ & $\begin{array}{r}1.15 \\
{[6.05]}\end{array}$ & $\begin{array}{r}1.14 \\
{[6.09]}\end{array}$ & $\begin{array}{r}1.23 \\
{[6.21]}\end{array}$ & $\begin{array}{r}1.20 \\
{[5.98]}\end{array}$ & $\begin{array}{r}1.21 \\
{[6.08]}\end{array}$ & $\begin{array}{r}1.19 \\
{[5.94]}\end{array}$ & $\begin{array}{r}1.17 \\
{[5.95]}\end{array}$ \\
\hline Year 6 & $\begin{array}{r}1.56 \\
{[7.73]}\end{array}$ & $\begin{array}{r}1.55 \\
{[7.65]}\end{array}$ & $\begin{array}{r}1.52 \\
{[7.59]}\end{array}$ & $\begin{array}{r}1.52 \\
{[7.65]}\end{array}$ & $\begin{array}{r}1.53 \\
{[7.79]}\end{array}$ & $\begin{array}{r}1.67 \\
{[7.85]}\end{array}$ & $\begin{array}{r}1.64 \\
{[7.77]}\end{array}$ & $\begin{array}{r}1.62 \\
{[7.73]}\end{array}$ & $\begin{array}{r}1.63 \\
{[7.82]}\end{array}$ & $\begin{array}{r}1.64 \\
{[7.79]}\end{array}$ \\
\hline Female & $\begin{array}{r}-0.24 \\
{[-2.40]}\end{array}$ & $\begin{array}{r}-0.22 \\
{[-2.23]}\end{array}$ & $\begin{array}{r}-0.22 \\
{[-2.32]}\end{array}$ & $\begin{array}{r}-0.22 \\
{[-2.25]}\end{array}$ & $\begin{array}{r}-0.21 \\
{[-2.19]}\end{array}$ & $\begin{array}{r}-0.24 \\
{[-1.84]}\end{array}$ & $\begin{array}{r}-0.17 \\
{[-1.58]}\end{array}$ & $\begin{array}{r}-0.19 \\
{[-1.71]}\end{array}$ & $\begin{array}{r}-0.18 \\
{[-1.63]}\end{array}$ & $\begin{array}{r}-0.17 \\
{[-1.56]}\end{array}$ \\
\hline ResJob & $\begin{array}{r}0.80 \\
{[6.46]}\end{array}$ & $\begin{array}{r}0.81 \\
{[6.48]}\end{array}$ & $\begin{array}{r}0.64 \\
{[4.78]}\end{array}$ & $\begin{array}{r}0.61 \\
{[4.50]}\end{array}$ & $\begin{array}{r}0.60 \\
{[4.38]}\end{array}$ & - & - & - & - & - \\
\hline ProdSup & $\begin{array}{r}0.05 \\
{[2.99]}\end{array}$ & $\begin{array}{r}0.04 \\
{[1.91]}\end{array}$ & $\begin{array}{r}0.03 \\
{[1.64]}\end{array}$ & $\begin{array}{r}0.03 \\
{[1.54]}\end{array}$ & $\begin{array}{r}0.02 \\
{[1.29]}\end{array}$ & $\begin{array}{r}0.04 \\
{[2.42]}\end{array}$ & $\begin{array}{r}0.02 \\
{[1.07]}\end{array}$ & $\begin{array}{r}0.02 \\
{[0.91]}\end{array}$ & $\begin{array}{r}0.02 \\
{[0.79]}\end{array}$ & $\begin{array}{r}0.01 \\
{[0.57]}\end{array}$ \\
\hline PhDUSA & $\begin{array}{r}-0.83 \\
{[-7.33]}\end{array}$ & $\begin{array}{r}-0.90 \\
{[-7.47]}\end{array}$ & $\begin{array}{r}-0.60 \\
{[-3.68]}\end{array}$ & $\begin{array}{r}-0.57 \\
{[-3.45]}\end{array}$ & $\begin{array}{r}-0.51 \\
{[-3.03]}\end{array}$ & $\begin{array}{r}-0.88 \\
{[-6.86]}\end{array}$ & $\begin{array}{r}-1.01 \\
{[-7.19]}\end{array}$ & $\begin{array}{r}-0.77 \\
{[-3.51]}\end{array}$ & $\begin{array}{r}-0.73 \\
{[-3.27]}\end{array}$ & $\begin{array}{r}-0.64 \\
{[-2.81]}\end{array}$ \\
\hline PhD10USA & - & $\begin{array}{r}0.19 \\
{[1.06]}\end{array}$ & $\begin{array}{r}0.15 \\
{[0.84]} \\
\end{array}$ & $\begin{array}{r}0.09 \\
{[0.45]}\end{array}$ & $\begin{array}{r}0.08 \\
{[0.41]} \\
\end{array}$ & - & $\begin{array}{r}0.39 \\
{[1.89]} \\
\end{array}$ & $\begin{array}{r}0.36 \\
{[1.69]}\end{array}$ & $\begin{array}{r}0.29 \\
{[1.21]}\end{array}$ & $\begin{array}{r}0.26 \\
{[1.07]}\end{array}$ \\
\hline PhD10EUR & - & $\begin{array}{r}-0.26 \\
{[-1.22]}\end{array}$ & $\begin{array}{r}-0.15 \\
{[-0.72]}\end{array}$ & $\begin{array}{r}-0.21 \\
{[-0.93]}\end{array}$ & $\begin{array}{r}-0.21 \\
{[-0.89]}\end{array}$ & - & $\begin{array}{r}-0.31 \\
{[-1.37]}\end{array}$ & $\begin{array}{c}-0.21 \\
{[-0.92]}\end{array}$ & $\begin{array}{r}-0.28 \\
{[-1.15]}\end{array}$ & $\begin{array}{r}-0.27 \\
{[-1.09]}\end{array}$ \\
\hline WrkUSA & - & - & $\begin{array}{r}0.49 \\
{[2.51]} \\
\end{array}$ & $\begin{array}{r}0.45 \\
{[2.33]}\end{array}$ & $\begin{array}{r}0.75 \\
{[3.44]} \\
\end{array}$ & - & - & $\begin{array}{r}0.31 \\
{[1.23]}\end{array}$ & $\begin{array}{r}0.26 \\
{[1.02]}\end{array}$ & $\begin{array}{r}0.58 \\
{[2.17]}\end{array}$ \\
\hline WrkEUR & - & - & $\begin{array}{r}0.71 \\
{[3.68]}\end{array}$ & $\begin{array}{r}0.72 \\
{[3.62]}\end{array}$ & $\begin{array}{r}0.77 \\
{[3.77]}\end{array}$ & - & - & $\begin{array}{r}0.49 \\
{[1.82]}\end{array}$ & $\begin{array}{r}0.48 \\
{[1.74]}\end{array}$ & $\begin{array}{r}0.54 \\
{[1.91]}\end{array}$ \\
\hline Wrk10USA & - & - & - & $\begin{array}{r}0.35 \\
{[1.39]}\end{array}$ & $\begin{array}{r}-0.04 \\
{[-0.11]}\end{array}$ & - & - & - & $\begin{array}{r}0.33 \\
{[1.27]}\end{array}$ & $\begin{array}{r}-0.07 \\
{[-0.18]}\end{array}$ \\
\hline Wrk10EUR & - & - & - & $\begin{array}{r}0.35 \\
{[1.24]}\end{array}$ & $\begin{array}{r}0.35 \\
{[1.24]}\end{array}$ & - & - & - & $\begin{array}{r}0.38 \\
{[1.42]}\end{array}$ & $\begin{array}{r}0.38 \\
{[1.40]}\end{array}$ \\
\hline $\begin{array}{l}\text { WrkUSA } \\
\text { European }\end{array}$ & - & - & - & - & $\begin{array}{c}-0.16 \\
{[-0.82]}\end{array}$ & - & - & - & - & $\begin{array}{r}-0.24 \\
{[-1.29]}\end{array}$ \\
\hline $\begin{array}{l}\text { WrkUSA } \\
\text { Other }\end{array}$ & - & - & - & - & $\begin{array}{c}-0.45 \\
{[-2.68]}\end{array}$ & - & - & - & - & $\begin{array}{r}-0.50 \\
{[-2.61]}\end{array}$ \\
\hline $\begin{array}{l}\text { Wrk10USA } \\
\text { European }\end{array}$ & - & - & - & - & $\begin{array}{c}0.68 \\
{[1.33]}\end{array}$ & - & - & - & - & $\begin{array}{r}0.76 \\
{[1.41]}\end{array}$ \\
\hline $\begin{array}{l}\text { Wrk10USA } \\
\text { Other }\end{array}$ & - & - & - & - & $\begin{array}{c}0.46 \\
{[0.93]}\end{array}$ & - & - & - & - & $\begin{array}{r}0.49 \\
{[0.96]}\end{array}$ \\
\hline Constant & $\begin{array}{r}-0.78 \\
{[-3.50]}\end{array}$ & $\begin{array}{r}-0.73 \\
{[-3.24]}\end{array}$ & $\begin{array}{r}-1.24 \\
{[-5.00]}\end{array}$ & $\begin{array}{r}-1.23 \\
{[-4.96]}\end{array}$ & $\begin{array}{l}-1.25 \\
{[-5.03]}\end{array}$ & $\begin{array}{r}-0.03 \\
{[-0.17]}\end{array}$ & $\begin{array}{r}0.05 \\
{[0.26]}\end{array}$ & $\begin{array}{r}-0.43 \\
{[-1.33]}\end{array}$ & $\begin{array}{r}-0.43 \\
{[-1.32]}\end{array}$ & $\begin{array}{r}-0.48 \\
{[-1.44]}\end{array}$ \\
\hline $\bar{N}$ & 822 & 822 & 822 & 822 & 822 & 543 & 543 & 543 & 543 & 543 \\
\hline
\end{tabular}


Table 6 - KMS Quality-Adjusted Publications (OLS regression)

\begin{tabular}{|c|c|c|c|c|c|c|c|c|c|c|}
\hline & \multicolumn{5}{|c|}{ Graduates from all universities } & \multicolumn{5}{|c|}{ Graduates placed at academic institutions } \\
\hline & $(1)$ & (2) & (3) & (4) & (5) & (6) & $(7)$ & (8) & (9) & $(10)$ \\
\hline Year 2 & $\begin{array}{r}1.31 \\
{[1.01]}\end{array}$ & $\begin{array}{r}1.41 \\
{[1.06]}\end{array}$ & $\begin{array}{r}1.14 \\
{[0.83]}\end{array}$ & $\begin{array}{r}0.54 \\
{[0.40]}\end{array}$ & $\begin{array}{r}0.29 \\
{[0.20]}\end{array}$ & $\begin{array}{r}1.72 \\
{[0.94]}\end{array}$ & $\begin{array}{r}1.82 \\
{[0.96]}\end{array}$ & $\begin{array}{r}1.94 \\
{[0.99]}\end{array}$ & $\begin{array}{r}1.06 \\
{[0.55]}\end{array}$ & $\begin{array}{r}0.62 \\
{[0.29]}\end{array}$ \\
\hline Year 3 & $\begin{array}{r}2.53 \\
{[1.69]}\end{array}$ & $\begin{array}{r}2.83 \\
{[1.88]}\end{array}$ & $\begin{array}{r}2.63 \\
{[1.72]}\end{array}$ & $\begin{array}{r}2.21 \\
{[1.43]}\end{array}$ & $\begin{array}{r}1.72 \\
{[1.09]}\end{array}$ & $\begin{array}{r}3.34 \\
{[1.59]}\end{array}$ & $\begin{array}{r}3.81 \\
{[1.79]}\end{array}$ & $\begin{array}{r}3.93 \\
{[1.82]}\end{array}$ & $\begin{array}{r}3.34 \\
{[1.53]}\end{array}$ & $\begin{array}{r}2.67 \\
{[1.19]}\end{array}$ \\
\hline Year 4 & $\begin{array}{r}6.59 \\
{[2.75]}\end{array}$ & $\begin{array}{r}6.49 \\
{[2.68]}\end{array}$ & $\begin{array}{r}6.16 \\
{[2.55]}\end{array}$ & $\begin{array}{r}5.09 \\
{[2.09]}\end{array}$ & $\begin{array}{r}4.66 \\
{[1.81]}\end{array}$ & $\begin{array}{r}8.52 \\
{[2.54]}\end{array}$ & $\begin{array}{r}8.20 \\
{[2.37]}\end{array}$ & $\begin{array}{r}7.83 \\
{[2.25]}\end{array}$ & $\begin{array}{r}6.68 \\
{[1.92]}\end{array}$ & $\begin{array}{r}6.28 \\
{[1.71]}\end{array}$ \\
\hline Year 5 & $\begin{array}{r}9.97 \\
{[3.75]}\end{array}$ & $\begin{array}{r}9.90 \\
{[3.69]}\end{array}$ & $\begin{array}{r}9.44 \\
{[3.58]}\end{array}$ & $\begin{array}{r}8.89 \\
{[3.56]}\end{array}$ & $\begin{array}{r}8.47 \\
{[3.66]}\end{array}$ & $\begin{array}{l}13.11 \\
{[3.39]}\end{array}$ & $\begin{array}{l}12.94 \\
{[3.30]}\end{array}$ & $\begin{array}{l}12.82 \\
{[3.28]}\end{array}$ & $\begin{array}{l}11.82 \\
{[3.24]}\end{array}$ & $\begin{array}{l}11.06 \\
{[3.30]}\end{array}$ \\
\hline Year 6 & $\begin{array}{l}15.07 \\
{[3.53]}\end{array}$ & $\begin{array}{l}14.75 \\
{[3.51]}\end{array}$ & $\begin{array}{l}14.37 \\
{[3.45]}\end{array}$ & $\begin{array}{l}14.34 \\
{[3.61]}\end{array}$ & $\begin{array}{l}13.67 \\
{[3.73]}\end{array}$ & $\begin{array}{l}23.25 \\
{[3.24]}\end{array}$ & $\begin{array}{l}22.66 \\
{[3.22]}\end{array}$ & $\begin{array}{l}22.47 \\
{[3.21]}\end{array}$ & $\begin{array}{l}22.46 \\
{[3.33}\end{array}$ & $\begin{array}{l}21.21 \\
{[3.40]}\end{array}$ \\
\hline Female & $\begin{array}{r}-2.68 \\
{[-1.55]}\end{array}$ & $\begin{array}{r}-2.12 \\
{[-1.28]}\end{array}$ & $\begin{array}{r}-2.34 \\
{[-1.41]}\end{array}$ & $\begin{array}{r}-2.18 \\
{[-1.37]}\end{array}$ & $\begin{array}{r}-2.38 \\
{[-1.60]}\end{array}$ & $\begin{array}{r}-4.55 \\
{[-1.78]}\end{array}$ & $\begin{array}{r}-3.71 \\
{[-1.52]}\end{array}$ & $\begin{array}{r}-4.21 \\
{[-1.73]}\end{array}$ & $\begin{array}{r}-3.99 \\
{[-1.69]}\end{array}$ & $\begin{array}{r}-4.40 \\
{[-1.98]}\end{array}$ \\
\hline ResJob & $\begin{array}{r}7.55 \\
{[4.76]}\end{array}$ & $\begin{array}{r}7.48 \\
{[4.76]}\end{array}$ & $\begin{array}{r}6.61 \\
{[4.20]}\end{array}$ & $\begin{array}{r}5.06 \\
{[3.65]}\end{array}$ & $\begin{array}{r}4.91 \\
{[3.45]}\end{array}$ & - & - & - & - & - \\
\hline ProdSup & $\begin{array}{r}1.83 \\
{[3.70]}\end{array}$ & $\begin{array}{r}1.48 \\
{[2.94]}\end{array}$ & $\begin{array}{r}1.43 \\
{[2.84]}\end{array}$ & $\begin{array}{r}1.32 \\
{[2.84]}\end{array}$ & $\begin{array}{r}0.98 \\
{[2.30]}\end{array}$ & $\begin{array}{r}2.36 \\
{[3.56]}\end{array}$ & $\begin{array}{r}1.81 \\
{[2.64]}\end{array}$ & $\begin{array}{r}1.80 \\
{[2.60]}\end{array}$ & $\begin{array}{r}1.66 \\
{[2.58]}\end{array}$ & $\begin{array}{r}1.22 \\
{[2.05]}\end{array}$ \\
\hline PhDUSA & $\begin{array}{r}-0.66 \\
{[-0.45]}\end{array}$ & $\begin{array}{r}-1.98 \\
{[-1.26]}\end{array}$ & $\begin{array}{r}-6.23 \\
{[-2.55]}\end{array}$ & $\begin{array}{r}-4.50 \\
{[-1.91]}\end{array}$ & $\begin{array}{r}-3.35 \\
{[-1.43]}\end{array}$ & $\begin{array}{r}-0.80 \\
{[-0.41]}\end{array}$ & $\begin{array}{c}-2.81 \\
{[-1.27]}\end{array}$ & $\begin{array}{r}-8.52 \\
{[-1.82]}\end{array}$ & $\begin{array}{r}-5.86 \\
{[-1.28]}\end{array}$ & $\begin{array}{r}-3.80 \\
{[-0.82]}\end{array}$ \\
\hline PhD10USA & - & $\begin{array}{r}6.21 \\
{[1.99]}\end{array}$ & $\begin{array}{r}6.13 \\
{[1.97]}\end{array}$ & $\begin{array}{r}2.63 \\
{[0.72]}\end{array}$ & $\begin{array}{r}3.42 \\
{[0.95]}\end{array}$ & & $\begin{array}{r}9.57 \\
{[2.09]}\end{array}$ & $\begin{array}{r}9.13 \\
{[2.00]}\end{array}$ & $\begin{array}{r}4.53 \\
{[0.81]}\end{array}$ & $\begin{array}{r}5.75 \\
{[1.02]}\end{array}$ \\
\hline PhD10EUR & - & $\begin{array}{r}-3.41 \\
{[-1.54]}\end{array}$ & $\begin{array}{r}-3.71 \\
{[-1.61]}\end{array}$ & $\begin{array}{r}-3.51 \\
{[-1.43]}\end{array}$ & $\begin{array}{r}-2.87 \\
{[-1.21]}\end{array}$ & & $\begin{array}{r}-2.76 \\
{[-0.98]}\end{array}$ & $\begin{array}{r}-3.49 \\
{[-1.10]}\end{array}$ & $\begin{array}{r}-3.32 \\
{[-0.98]}\end{array}$ & $\begin{array}{r}-2.29 \\
{[-0.71]}\end{array}$ \\
\hline WrkUSA & - & - & $\begin{array}{r}5.30 \\
{[3.62]}\end{array}$ & $\begin{array}{r}3.64 \\
{[2.60]}\end{array}$ & $\begin{array}{r}6.61 \\
{[2.24]}\end{array}$ & & & $\begin{array}{r}7.99 \\
{[3.24]}\end{array}$ & $\begin{array}{r}5.29 \\
{[2.25]}\end{array}$ & $\begin{array}{r}6.15 \\
{[1.68]}\end{array}$ \\
\hline WrkEUR & - & - & $\begin{array}{r}-1.28 \\
{[-0.66]}\end{array}$ & $\begin{array}{r}0.09 \\
{[0.05]}\end{array}$ & $\begin{array}{r}0.78 \\
{[0.39]}\end{array}$ & & & $\begin{array}{r}-0.07 \\
{[-0.02]}\end{array}$ & $\begin{array}{r}1.11 \\
{[0.31]}\end{array}$ & $\begin{array}{r}2.42 \\
{[0.66]}\end{array}$ \\
\hline Wrk10USA & - & - & - & $\begin{array}{l}27.86 \\
{[2.12]}\end{array}$ & $\begin{array}{l}50.26 \\
{[2.24]}\end{array}$ & & & & $\begin{array}{l}25.20 \\
{[1.88}\end{array}$ & $\begin{array}{l}48.64 \\
{[2.13]}\end{array}$ \\
\hline Wrk10EUR & - & - & - & $\begin{array}{r}3.49 \\
{[0.60]}\end{array}$ & $\begin{array}{r}3.77 \\
{[0.66]}\end{array}$ & & & & $\begin{array}{r}2.97 \\
{[0.45]}\end{array}$ & $\begin{array}{r}3.15 \\
{[0.48]}\end{array}$ \\
\hline WrkUSA European & & & & & $\begin{array}{r}-0.96 \\
{[-0.24]}\end{array}$ & & & & & $\begin{array}{r}0.32 \\
{[0.07]}\end{array}$ \\
\hline WrkUSA Other & & & & & $\begin{array}{r}-3.83 \\
{[-1.12]}\end{array}$ & & & & & $\begin{array}{r}-1.06 \\
-0.24]\end{array}$ \\
\hline Wrk10USA European & & & & & $\begin{array}{l}-11.11 \\
{[-0.21]}\end{array}$ & & & & & $\begin{array}{l}-11.58 \\
{[-0.22]}\end{array}$ \\
\hline Wrk10USA Other & & & & & $\begin{array}{l}-45.16 \\
{[-1.92}\end{array}$ & & & & & $\begin{array}{l}-45.98 \\
{[-1.92}\end{array}$ \\
\hline constant & $\begin{array}{r}-6.72 \\
{[-2.91]}\end{array}$ & $\begin{array}{r}-6.31 \\
{[-2.68]}\end{array}$ & $\begin{array}{r}-4.30 \\
{[-1.94]}\end{array}$ & $\begin{array}{r}-3.96 \\
{[-1.83]}\end{array}$ & $\begin{array}{r}-3.80 \\
-1.78]\end{array}$ & $\begin{array}{r}-2.15 \\
{[-0.95]}\end{array}$ & $\begin{array}{r}-1.36 \\
{[-0.57]}\end{array}$ & $\begin{array}{r}-1.13 \\
{[-0.28]}\end{array}$ & $\begin{array}{r}-1.74 \\
{[-0.42]}\end{array}$ & $\begin{array}{r}-2.02 \\
{[-0.48]}\end{array}$ \\
\hline $\mathrm{N}$ & 822 & 822 & 822 & 822 & 822 & 543 & 543 & 543 & 543 & 543 \\
\hline
\end{tabular}




\section{Appendix A: Coding of country region}

The coding of regions follows the United Nations Educational, Scientific and Cultural Organization (UNESCO) "definition of regions with a view to the execution by the Organization of regional activities". All countries in the UNESCO "Europe and North America" region were coded as Europe, with the exception of the Russian Federation, Turkey, Kazakhstan and Tajikistan, which UNESCO includes both under Europe and Asia. We have opted to include them under Asia, as it matches more closely the geography. As such, the following countries are coded as Europe:

$\begin{array}{lll}\text { Albania } & \text { France } & \text { Norway } \\ \text { Andorra } & \text { Georgia } & \text { Poland } \\ \text { Armenia } & \text { Germany } & \text { Portugal } \\ \text { Austria } & \text { Greece } & \text { Republic of Moldova } \\ \text { Azerbaijan } & \text { Hungary } & \text { Romania } \\ \text { Belarus } & \text { Iceland } & \text { San Marino } \\ \text { Belgium } & \text { Ireland } & \text { Serbia } \\ \text { Bosnia and Herzegovina } & \text { Israel } & \text { Slovakia } \\ \text { Bulgaria } & \text { Italy } & \text { Slovenia } \\ \text { Croatia } & \text { Latvia } & \text { Spain } \\ \text { Cyprus } & \text { Lithuania } & \text { Sweden } \\ \text { Czech Republic } & \text { Luxembourg } & \text { Switzerland } \\ \text { Denmark } & \text { Malta } & \text { The former Yugoslav Republic of Macedonia } \\ \text { Estonia } & \text { Monaco } & \text { Ukraine } \\ \text { Finland } & \text { Montenegro } & \text { United Kingdom and Northern Ireland } \\ & \text { Netherlands } & \end{array}$

Source: UNESCO (2008). 


\section{Appendix B}

Shares of articles by JEL code: Counts and KMS

\begin{tabular}{|c|c|c|}
\hline $\begin{array}{l}\text { Count } \\
1.1 \%\end{array}$ & $\begin{array}{l}\text { KMS } \\
\qquad 1.4 \%\end{array}$ & $\begin{array}{r}\text { JEL Code } \\
\text { A - General Economics and Teaching }\end{array}$ \\
\hline $2.2 \%$ & $1.0 \%$ & B - Schools of Economic Thought and Methodology \\
\hline $4.6 \%$ & $18.2 \%$ & C - Mathematical and Quantitative Methods \\
\hline $9.4 \%$ & $20.2 \%$ & D - Microeconomics \\
\hline $7.8 \%$ & $9.6 \%$ & E - Macroeconomics and Monetary Economics \\
\hline $8.5 \%$ & $5.7 \%$ & F - International Economics \\
\hline $10.8 \%$ & $6.4 \%$ & G - Financial Economics \\
\hline $4.4 \%$ & $4.3 \%$ & $\mathrm{H}$ - Public Economics \\
\hline $4.7 \%$ & $3.5 \%$ & I - Health, Education and Welfare \\
\hline $8.6 \%$ & $9.4 \%$ & $\mathrm{~J}$ - Labor and Demographic Economics \\
\hline $1.7 \%$ & $1.0 \%$ & $\mathrm{~K}$ - Law and Economics \\
\hline $8.5 \%$ & $5.8 \%$ & L - Industrial Organization \\
\hline $2.7 \%$ & $0.9 \%$ & M - Business Administration and Business Economics \\
\hline $1.6 \%$ & $1.1 \%$ & $\mathrm{~N}$ - Economic History \\
\hline $8.5 \%$ & $5.3 \%$ & O - Economic Development \\
\hline $2.9 \%$ & $1.1 \%$ & P - Economic Systems \\
\hline $6.5 \%$ & $3.2 \%$ & Q - Agricultural and Natural Resource Economics \\
\hline $4.6 \%$ & $1.5 \%$ & R - Urban, Rural and Regional Economics \\
\hline $0.4 \%$ & $0.0 \%$ & Y - Miscellaneous Categories \\
\hline $0.4 \%$ & $0.0 \%$ & Z - Other Special Topics \\
\hline
\end{tabular}

